\title{
ANALISIS PENGARUH KONEKSI MILITER TERHADAP TINGKAT SUKU BUNGA DI PERUSAHAAN-PERUSAHAAN INDONESIA
}

\author{
Budi Harsono dan Christina Kwok* \\ * Jurusan Akuntansi, Fakultas Ekonomi \\ Universitas Internasional Batam \\ Email: christinakwok97@gmail.com
}

\begin{abstract}
The purpose of this study is to provides direct empirical evidence on the effect of military connections on interest rate for listed firms in Indonesia. Purposive sampling was implemented in this study. This study used 2.107 data companies listed on IDX in the period 2013-2017. The results show that firm size and growth have the significant impact on interest rate in both positive and negative ways. While military connections, return on assets, leverage, and market to book value were not able to affect interest rate activity significantly
\end{abstract}

Keywords: military connections, interest rate, bank loan, developing country

\section{INTRODUCTION}

Boediono (2014) mengungkapkan tingkat suku bunga dapat didefinisikan sebagai proporsi biaya yang dipinjamkan oleh pemberi pinjaman sebagai bunga kepada peminjam, biasanya dinyatakan sebagai persentase dari jumlah total pinjaman, hal ini adalah kurs yang dikenakan oleh bank atau pemberi pinjaman lain untuk meminjam uangnya, atau kurs yang dibayarkan bank kepada penabungnya untuk menyimpan uang dalam rekening. Sukirno (2006) menjelaskan tingkat suku bunga mempengaruhi inflasi secara tidak langsung melalui permintaan barang dan jasa dalam negeri dan melalui pengaruhnya terhadap nilai tukar.Secara umum, ketika suku bunga dikurangi, lebih banyak orang dapat meminjam lebih banyak uang.Hasilnya adalah konsumen memiliki lebih banyak uang untuk dibelanjakan menyebabkan ekonomi tumbuh dan inflasi meningkat.Kebalikannya jika suku bunga dinaikkan, konsumen cenderung menabung karena pengembalian dari tabungan lebih tinggi. Hal ini dapat dikatakan dengan berkurangnya pendapatan yang dibuang sebagai hasil dari kenaikan suku bunga, maka ekonomi melambat dan inflasi menurun (Madura, 2009).

Para masyarakat berkeinginan menabung apabila tingkat suku bunga meningkat, ini merupakan salah satu fungsi dari tingkat suku bunga. Fungsi lain dari tingkat suku bunga adalah investasi, dimana tingkat bunga semakin tinggi, maka semakin kecil keinginan masyarakat untuk berinvestasi. Para investor akan berinvestasi jika tingkat bunga rendah sebab biaya yang ditanggung semakin kecil dengan harapan profit yang besar (Nopirin, 2000).

Berdasarkan teori Keynes (2004) faktor penentu tingkat suku bunga adalah fenomena moneter. Analisis Keynes (2004) merujuk pada permintaan dan penawaran uang sebagai penentu tingkat bunga. Bunga dapat diartikan sebagai harga yang dibayarkan untuk dana pinjaman. Orang-orang lebih memilih menyimpan uang dengan mereka daripada menginvestasikan uang tunai dalam aset.

Keynes (2004) berpendapat bahwa faktor-faktor seperti pantang dan preferensi waktu tidak ada hubungannya dengan pembayaran tingkat bunga. Menurutnya bunga bukanlah kompensasi kepada penabung untuk pantangan yang telah ia jalani atau preferensi waktu yang dimilikinya. Dengan kata lain, tingkat bunga bagi Keynes ialah untuk menerima klaim seperti obligasi dan keamanan sebagai pengganti uang. 
Menurut Arikunto (2011) suku bunga adalah salah satu aspek terpenting dari sistem ekonomi Amerika. Mereka mempengaruhi biaya pinjaman, pengembalian atas tabungan, dan merupakan komponen penting dari total pengembalian banyak investasi. Selain itu, suku bunga tertentu memberikan wawasan tentang kegiatan ekonomi dan pasar keuangan di masa depan.

Mishkin (2008) mengungkapkan adanya persaingan suku bunga di Indonesia bukanlah sesuatu yang asing sebab pada dasarnya setiap bank memang diberi kebebasan untuk memberikan suku bunga yang berbeda beda. Hal ini dapat dikatakan sebagai salah satu strategi pemasaran karena kita mengetahui terkadang nasabah cenderung lebih memilih bank yang berani memberikan suku bunga pinjaman yang rendah dan suku bunga tabungan serta deposito yang terbilang cukup tinggi.

Suku bunga merupakan salah satu angka terpenting dalam perekonomian karena mereka memengaruhi seberapa besar kemungkinan orang meminjam uang. Jika suku bunga tinggi, maka itu akan sangat mahal untuk meminjam uang. Saat rendah, harganya jauh lebih murah.Ketika orang meminjam uang, mereka biasa menggunakannya untuk berinvestasi dalam hal-hal besar seperti rumah atau bisnis baru. Investasi ini bergejolak ke seluruh perekonomian dan dapat meningkatkan pertumbuhan pekerjaan atau bahkan upah (Judisseno, 2002).

Fungsi penting bunga dalam ekonomi pasar adalah koordinasi antara penabung dan peminjam. Penabung dibayar bunga untuk menunda konsumsi mereka sampai masa depan, sementara peminjam harus membayar bunga untuk mengkonsumsi lebih banyak di masa sekarang. Suku bunga mempengaruhi berapa banyak uang pinjaman bank baru yang beredar dalam perekonomian, mereka memiliki dampak langsung pada pengganda simpanan dan inflasi (Peter Wilson, 2012).
Berdasarkan latar belakang yang telah diuraikan diatas, maka penulis tertarik melakukan penelitian dengan pembahasan mengenai "ANALISIS MENGAPA PERUSAHAAN MENUNJUK MANTAN PERSONEL MILITER SEBAGAI DIREKTUR? SERTA BUKTI TINGKAT SUKU BUNGA PINJAMAN DI PERUSAHAAN-PERUSAHAAN YANG TERHUBUNG SECARA MILITER DI INDONESIA"

\section{LITERATURE REVIEW AND HYPOTHESIS DEVELOPMENT}

Sukirno (2011) mengungkapkan definisi bunga ialah pembayaran atas modal yang dipinjam oleh pihak lain dan dibayar oleh peminjam dana sejumlah persentase yang disepakati oleh kedua belah pihak. Arti lain dari bunga juga bisa dikatakan sebagai harga dari dana investasi. Modal dinyatakan sebagai tingkat suku bunga, sedangkan bunga dinamakan sebagai persentase.

Suku bunga merupakan salah satu angka terpenting dalam perekonomian karena mereka memengaruhi seberapa besar kemungkinan orang meminjam uang. Jika suku bunga tinggi, maka itu akan sangat mahal untuk meminjam uang. Saat rendah, harganya jauh lebih murah.Ketika orang meminjam uang, mereka biasa menggunakannya untuk berinvestasi dalam hal-hal besar seperti rumah atau bisnis baru. Investasi ini bergejolak ke seluruh perekonomian dan dapat meningkatkan pertumbuhan pekerjaan atau bahkan upah (Judisseno, 2002).

Menurut Dendawijaya (2009) Suku bunga jangka panjang mengacu pada obligasi pemerintah yang jatuh tempo dalam sepuluh tahun. Suku bunga terutama ditentukan oleh harga yang dikenakan oleh pemberi pinjaman, risiko dari peminjam dan penurunan nilai modal.Suku bunga jangka panjang umumnya adalah rata-rata suku bunga harian, diukur sebagai persentase. Suku bunga ini tersirat oleh harga di mana obligasi pemerintah 
diperdagangkan di pasar keuangan, bukan suku bunga dimana pinjaman diterbitkan. Dalam semua kasus, mereka merujuk pada obligasi yang pembayaran modalnya dijamin oleh pemerintah. Suku bunga jangka panjang adalah salah satu penentu investasi bisnis. Suku bunga jangka panjang yang rendah mendorong investasi pada peralatan baru dan suku bunga tinggi mencegahnya (Samsul Arifin, 2006).

Suku bunga terbagi menjadi dua kekuatan, yaitu permintaan investasi modal dan penawaran tabungan dari sektor bisnis, diketahui juga bahwa hukum permintaan dan penawaran terus berlaku di pasar keuangan (Sunariyah, 2013). Menurut hukum permintaan, tingkat pengembalian yang lebih tinggi akan menurunkan kuantitas yang diminta. Ketika tingkat bunga naik, konsumen akan mengurangi jumlah yang mereka pinjam. Menurut hukum penawaran, harga yang lebih tinggi meningkatkan kuantitas yang disediakan. Akibatnya, ketika tingkat bunga yang dibayarkan untuk pinjaman kartu kredit naik, lebih banyak perusahaan yang bersemangat untuk mengeluarkan kartu kredit dan mendorong pelanggan untuk menggunakannya. Sebaliknya, jika tingkat bunga kartu kredit turun, jumlah modal keuangan yang dipasok di pasar kartu kredit akan menurun dan jumlah yang diminta akan turun (Keynes, 2009).

Tingkat suku bunga dapat didefinisikan sebagai proporsi biaya yang dipinjamkan oleh pemberi pinjaman sebagai bunga kepada peminjam, biasanya dinyatakan sebagai persentase dari jumlah total pinjaman, hal ini adalah kurs yang dikenakan oleh bank atau pemberi pinjaman lain untuk meminjam uangnya, atau kurs yang dibayarkan bank kepada penabungnya untuk menyimpan uang dalam rekening (Boediono, 2014)

Menurut Mishkin (1995) elemen kunci dalam mekanisme transmisi moneter adalah kemampuan bank sentral untuk mempengaruhi tingkat bunga riil. Perubahan tingkat bunga riil menyebabkan perubahan pengeluaran untuk barang tahan lama, yang merupakan komponen dari pengeluaran keseluruhan.Tetapi ada juga saluran pengaruh lainnya. Jika Federal Reserve mengurangi suku bunga, maka permintaan dolar untuk berinvestasi di pasar aset AS akan berkurang. Ini akan mengurangi harga mata uang asing dolar. Dolar yang rendah berarti barang yang diproduksi di Amerika Serikat lebih murah, sehingga ekspor AS akan meningkat, dan impor AS akan menurun. Jadi perubahan dalam tingkat bunga menyebabkan perubahan dalam nilai tukar, yang pada gilirannya menyebabkan perubahan dalam ekspor neto. Ekspor bersih juga merupakan komponen dari pengeluaran keseluruhan (Bernanke dan Blinder, 1992).

Keynes (2004) berpendapat bahwa faktor-faktor seperti pantang dan preferensi waktu tidak ada hubungannya dengan pembayaran tingkat bunga. Menurutnya bunga bukanlah kompensasi kepada penabung untuk pantangan yang telah ia jalani atau preferensi waktu yang dimilikinya. Dengan kata lain, tingkat bunga bagi Keynes ialah untuk menerima klaim seperti obligasi dan keamanan sebagai pengganti uang.

Suku bunga adalah bentuk risiko keuangan yang berkaitan dengan efek pergerakan suku bunga pada kinerja keuangan masa depan perusahaan dan dapat memanifestasikan dirinya dalam salah satu dari tiga cara yang berbeda (Agustianto, 2005) sebagai berikut :

1. Hutang suku bunga variabel dapat meningkatkan biaya pendanaan untuk perusahaan saat suku bunga naik dan dapat mempengaruhi laba perusahaan. Ketika kenaikan suku bunga cukup besar, perusahaan dapat menderita kesulitan keuangan.

2. Hasil atas investasi berbunga perusahaan akan menurun dalam periode penurunan suku bunga dan cash-rich companies mungkin mengetahui bahwa penurunan suku bunga terbukti rugi bagi mereka. 
3. Tingginya tingkat pendanaan dengan suku bunga tetap selama periode penurunan suku bunga dapat mengakibatkan biaya peluang, di mana perusahaan dengan utang suku bunga membayar tingkat bunga yang lebih tinggi daripada rekan-rekan mereka dengan utang suku bunga yang mengambang rendah. Meskipun risiko ini dapat mengakibatkan kerugian kompetitif yang cukup besar, risiko ini tidak pernah dilaporkan dalam laporan keuangan tahunan perusahaan.

Kasmir (2004) mengungkapkan agar mendapatkan laba yang diperoleh, maka pihak manajemen bank harus pandai mendefinisikan besar kecilnya komponen suku bunga. Ada tujuh faktor yang bisa memberi pengaruh terhadap penentuan suku bunga, sebagai berikut:

\section{Skor Kredit}

Skor kredit merupakan faktor yang mampu memberi pengaruh tingkat bunga.Secara umum, konsumen dengan skor kredit yang lebih tinggi menerima suku bunga yang lebih rendah daripada konsumen dengan skor kredit yang lebih rendah.

\section{Home Location}

Lokasi dimana kita memilih untuk membeli juga dapat mempengaruhi suku bunga.Banyak pemberi pinjaman mungkin memiliki tingkat yang berbeda tergantung pada negara tempat kita tinggal.Secara umum, bank lokal dan pemberi pinjaman nasional besar mungkin memiliki opsi terbatas sementara broker hipotek dapat menawarkan spektrum produk yang lebih luas dan kisaran tarif.Penting untuk memeriksa dengan beberapa tempat sehingga kita bisa mendapatkan lebih dari satu pendapat.

3. Harga Rumah dan Jumlah Pinjaman Pembeli dapat membayar suku bunga yang lebih tinggi untuk pinjaman yang sangat kecil atau besar.Jumlah yang harus dipinjam untuk pinjaman hipotek adalah harga rumah ditambah biaya penutupan dikurangi uang muka.Tergantung pada keadaan atau jenis pinjaman hipotek.

4. Jumlah Uang Muka Secara umum, uang muka yang lebih besar berarti tingkat bunga yang lebih rendah, karena pemberi pinjaman melihat tingkat risiko yang lebih rendah ketika memiliki lebih banyak saham di properti.

5. Jangka Waktu Pinjaman

Jangka waktu pinjaman adalah berapa lama kita harus membayar kembali pinjaman.Secara umum, pinjaman jangka pendek memiliki tingkat bunga yang lebih rendah dan biaya keseluruhan yang lebih rendah, tetapi pembayaran bulanan lebih tinggi.Banyak hal yang tergantung pada spesifiknya, seperti seberapa jauh jumlah yang lebih rendah dari pembayaran bunga dan seberapa besar pembayaran bulanan tergantung pada panjang pinjaman yang dilihat serta tingkat bunga.

6. Jenis Suku Bunga

Ada dua jenis tipe suku bunga yaitu suku bunga tetap dan suku bunga yang dapat disesuaikan. Suku bunga pinjaman dengan suku bunga tetap akan tetap konstan selama umur pinjaman. Pinjaman yang dapat disesuaikan memiliki suku bunga yang mungkin ditetapkan untuk jumlah waktu tertentu di awal dan kemudian menyesuaikan naik atau turun setiap periode berdasarkan pasar.

7. Jenis Pinjaman

Jenis pinjaman yang digunakan untuk hipotek akan memengaruhi tingkat bunga. Ada beberapa kategori berbeda dalam jenis hipotek yaitu FHA (Federal Housing Administration), USDA (United States Department of

Program Studi Akuntansi, Fakultas Ekonomi, Universitas Internasional Batam | 66 
Agriculture), VA (Department of Veterans Affairs) dan Conventional Loans.

Keynes (1936) menganalisis bahwa ekonomi berada dalam jebakan likuiditas, atau tidak ada koordinasi antara tabungan dan investasi, maka dari itu perlu untuk melenyapkan tingkat suku bunga agar mendapatkan keseimbangan di pasar uang. Dalam situasi ini, tidak mungkin menggunakan kebijakan moneter untuk mengatasi krisis karena suku bunga nol. Pada dasarnya, jebakan likuiditas terjadi karena hubungan yang buruk antara tingkat pengembalian produksi di sektor riil dan tingkat bunga. Dalam hal ini tingkat bunga telah menurun ke angka yang sangat rendah, terlepas dari tingkat produktivitasnya. Salah satu alasan di balik situasi ini adalah peningkatan risiko investasi, yang mengurangi hasil investasi bersih. Dengan cara lain, kita dapat mengatakan bahwa jika dimungkinkan untuk membuat tingkat bunga negatif dalam perekonomian, yang secara praktis tidak mungkin, kebijakan moneter akan mampu mengatasi krisis.

Kim, Song, dan Zhang (2011) menganalisis bukti yang menyakinkan bahwa bank membebankan perusahaan ICW (internal control weaknesses) dengan tingkat bunga yang lebih tinggi daripada perusahaan non-ICW (internal control weaknesses) untuk mengkompensasi risiko informasi. Peneliti juga mengklaim bahwa pengungkapan ICW dibawah SOX 404 berisi informasi baru untuk pemberi pinjaman swasta.Peneliti melaporkan bahwa bank meningkatkan suku bunga setelah peminjam mengungkapkan kekurangan kontrol internal dalam bagian pengajuan 404, dapat disimpulkan juga bahwa ini didasarkan pada perbandingan sederhana dalam persyaratan kontrak sebelum dan sesudah pengungkapan sampel yang cocok dengan tiga fitur pinjaman.

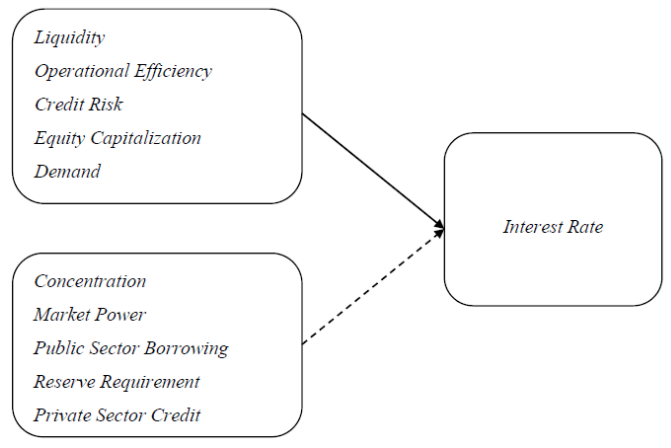

Gambar 1 Model penelitian pengaruh penentu tingkat bunga di pasar Negara berkembang. Sumber : Demirgüç-Kunt dan Huizinga (1999).

Bose (2002) menganalisis metodemetode perubahan dalam tingkat bunga kemungkinan akan berdampak pada tingkat harga dalam model makro standar yang dapat dibedakan menjadi metode permintaan dan penawaran. Sisi permintaan ekonomi ditentukan oleh kondisi ekuilibrium di pasar uang dan barang.Pertama, pertimbangkan dampak kenaikan suku bunga di pasar uang.Kenaikan suku bunga meningkatkan biaya peluang dalam memegang saldo kas yang berdampak negatif pada permintaan uang.Pengurangan dalam permintaan uang menciptakan kelebihan pasokan kredit dan mendorong peningkatan jumlah permintaan. Akibatnya, harga harus meningkat sehingga orang-orang akan senang untuk memegang stok uang yang ada daripada membelanjakannya untuk komoditas atau aset yang mengandung bunga.

Ha dan Choi (2010) menganalisis penelitian mengenai bagaimana perubahan kesadaran konsumen tentang suku bunga di Korea dapat mempengaruhi loyalitas pelanggan, mengingat upaya bank untuk meningkatkan orientasi pelanggan.Peneliti secara jelas merasionalisasi fakta yang menjadi kesadaran konsumen suku bunga dapat memainkan peran penting dalam memoderasi pengaruh hubungan antara orientasi dan loyalitas pelanggan.Peneliti telah lama berfokus pada "sensitivitas tingkat bunga" untuk memprediksi tindakan lebih lanjut pengguna perbankan 
atau pengembalian lainnya daripada membahas arti penting tingkat bunga itu sendiri.

Sensitivitas tingkat bunga menggambarkan perbedaan relatif dalam penilaian pelanggan terhadap perbedaan suku bunga di antara produk-produk perbankan yang bersaing.Penilaian pelanggan dianggap sebagai konsep luas kesadaran tingkat bunga, sedangkan kesadaran konsumen tentang bunga pinjaman dan deposito mengacu pada tingkat kesadaran mereka tentang tingkat bunga riil di mana masing-masing karakteristik dari dua suku bunga dengan jelas disampaikan kepada pelanggan perbankan. Misalnya, jika Bank of Korea menurunkan suku bunga sebesar 0,25 persen, pelanggan perbankan tidak akan yakin tentang efek gelombang kedua potensial pada tingkat bunga riil yang akan mereka terima dari bank. Namun, kesadaran konsumen tentang tingkat bunga riil yang tergantung pada tingkat dasar dalam industri perbankan, dapat memberi mereka pesan yang jelas dan pemahaman yang lebih baik tentang perubahan suku bunga awal dan selanjutnya. Secara logis, suku bunga dalam penelitian ini adalah suku bunga bank atau pasar umum, yang mencerminkan suku bunga yang berlaku pada setoran tunai atau pinjaman, yang ditentukan oleh perubahan suku bunga dasar Bank Korea (Ha dan Choi, 2010).

$$
\text { Imam Harymawan }
$$

melakukan penelitian dengan tujuan untuk memberikan bukti empiris tentang pengaruh koneksi militer terhadap tingkat suku bunga pada perusahaan-perusahaan yang terdaftar di Indonesia, untuk menganalisis empiris peneliti membuat sampel perusahaan yang tercatat di BEI pada tahun 2004 hingga 2012. Peneliti kemudian menguji hubungan antara utang tingkat suku bunga terhadap perusahaanperusahaan yang terhubung secara militer dan yang tidak terhubung secara militer. Lebih khususnya lagi, peneliti memeriksa apakah perusahaan dengan koneksi militer dikaitkan dengan suku bunga yang lebih rendah. Menurut peneliti fungsi ganda peran militer di Indonesia ada kemungkinan bahwa personil militer dapat memberikan beberapa keuntungan dengan menggunakan kekuatan politik mereka ke perusahaan yang terhubung. Jika ini masalahnya, diharapkan para direktur yang terhubung secara militer dapat memberikan keuntungan atau manfaat bagi perusahaan, maka hasilnya perusahaan yang terhubung secara militer akan memiliki tingkat bunga yang jauh lebih rendah daripada yang tidak terhubung secara militer.

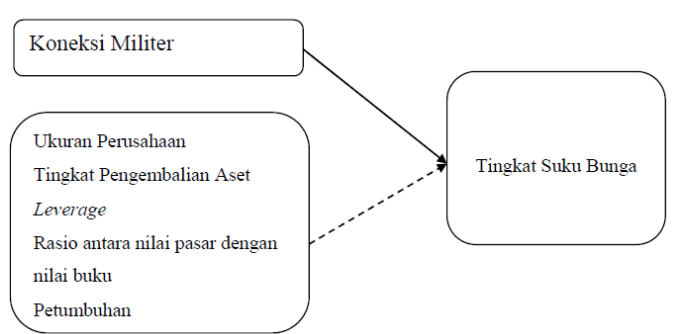

Gambar 2 Model penelitian pengaruhkoneksi militer terhadap tingkat suku bunga di perusahaan-perusahaan Indonesia. Sumber : Imam Harymawan (2017).

Koneksi militer dapat didefinisikan sebagai pengganti kualitas tata kelola yang dibutuhkan oleh perusahaan untuk mengurangi biaya bunga di negara berkembang. Peneliti menemukan bahwa di Indonesia, militer juga memainkan peran yang sama sebagai politikus yang memberikan manfaat bagi koneksi bisnis dengan menggunakan pengaruh baik atau buruknya koneksi politik dan koneksi militer (Crouch, 1978).

$$
\text { Crouch (1978) melakukan }
$$
penelitian dengan hasil bahwa dengan membangun koneksi politik dan koneksi militer, perusahaan di negara berkembang dapat memperoleh akses preferensial terhadap pembiayaan. Dengan kata lain, koneksi semacam itu merupakan pengganti kualitas tata kelola yang dibutuhkan oleh perusahaan untuk mengurangi biaya bunga di negara berkembang. Peneliti juga sebelumnya menemukan bahwa di Indonesia, militer memiliki peran yang sama dengan politikus yang dapat 
memberikan manfaat bagi koneksi bisnis mereka.

Berdasarkan penelitian yang dilakukan oleh Pittman dan Fortin (2004) mengenai ukuran perusahaan hasil penelitian tersebut menunjukkan bahwa perusahaan yang terhubung memiliki tingkat suku bunga (IRATE) yang jauh lebih rendah daripada yang tidak terhubung. Sehubungan dengan SIZE, perusahaan dengan koneksi militer secara signifikan lebih besar daripada perusahaan tanpa koneksi militer dan lebih cenderung memiliki penyebaran pinjaman bank yang lebih tinggi.Peneliti menemukan bahwa dalam semua spesifikasi, ukuran perusahaan adalah penentu penting dalam kemungkinan membangun koneksi militer.

Tingkat pengembalian aset adalah rasio yang dapat mencerminkan sejauh manakah kemampuan aset pada perusahaan agar bisa menghasilkan laba. Berdasarkan pengertiannya, maka dapat dikatakan pula bahwa ROA didefinisikan sebagai rasio yang mengukur seberapa efektif sebuah perusahaan dalam mengelola asetnya untuk menghasilkan laba selama suatu periode (Eduardus Tandelilin, 2010).

Kim et al (2011) menyatakan perusahaan yang terhubung memiliki pengembalian aset yang jauh lebih rendah daripada perusahaan yang tidak terhubung, selain itu perusahaan yang terhubung memiliki jarak yang jauh lebih singkat antara markas perusahaan dan pangkalan militer indonesia daripada yang tidak terhubung, sedangkan perusahaan dengan tingkat pengembalian aset yang lebih rendah secara signifikan terkait dengan tingkat bunga utang yang lebih tinggi.

Leverage merupakan penggunaan aset serta sumber dana oleh perusahaan dimana dalam penerapan aset atau dana perusahaan harus menghasilkan biaya tetap. Tujuan dari perusahaan menggunakan rasio leverage supaya keuntungan yang diterima lebih besar daripada penggunaan aset dan sumber dananya (Syamsuddin, 2002).
Kim et al (2011) melakukan penelitian mengenai leverage sebagai wakil untuk risiko kebangkrutan. Perusahaan dengan leverage yang lebih tinggi secara signifikan terkait dengan tingkat bunga utang yang lebih tinggi. Perusahaan dengan koneksi militer memiliki leverage perusahaan yang lebih rendah. Perusahaan yang terhubung secara militer lebih cenderung terpusat dibeberapa industri tertentu. Dengan kata lain, perusahaan-perusahaan dengan kantor pusat yang lebih dekat dengan pangkalan militer Indonesia lebih mungkin untuk membangun koneksi militer.

Nilai pasar mewakili nilai perusahaan sesuai dengan pasar saham. Nilai pasar juga biasa digunakan untuk merujuk pada kapitalisasi pasar dari perusahaan publik, dan dapat diperoleh dengan cara harga saham dikalikan dengan jumlah saham yang beredar (Jogiyanto, 2000).

Nilai buku merupakan nilai dari suatu bisnis berdasarkan "buku" atau laporan keuangannya serta dikalkulasikan dari neraca yang merupakan selisih antara total aset dan total liabilitas. Nilai buku suatu aset bisa dipengaruhi oleh metode penyusutan, hal ini menyebabkan bahwa dalam periode tertentu nilai buku suatu aset bisa berbeda dari satu perusahaan dengan perusahaan yang lain (Jogiyanto, 2003).

Pertumbuhan adalah salah satu bagian yang menentukan susunan modal perusahaan, selain itu perusahaan yang tumbuh dapat dikatakan tumbuh lebih cepat dari perusahaan sejenis atau ekonomi yang lebih luas. Pertumbuhan juga dapat dideskripsikan sebagai perubahan aset tahunan dari total aktiva (Brigham \& Houston, 2001).

Kim et al (2011) melakukan penelitian mengenai pertumbuhan yang menunjukkan bahwa pertumbuhan mengendalikan efek potensial dari pertumbuhan perusahaan pada tingkat suku bunga serta tidak ada perbedaan dalam pertumbuhan antara perusahaan yang 
terhubung dan yang tidak terhubung. Perusahaan yang terhubung secara militer dikaitkan dengan pertumbuhan perusahaan yang lebih tinggi.

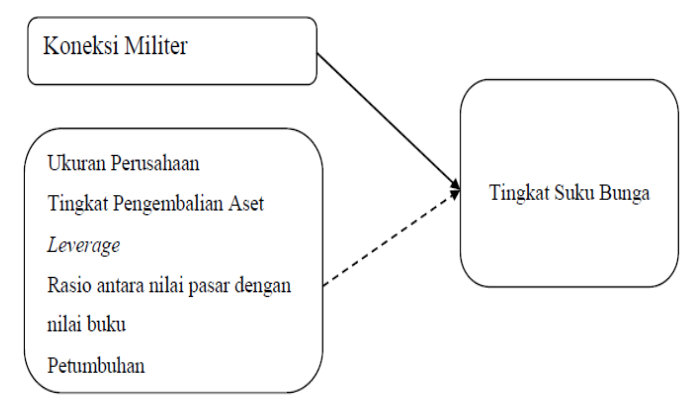

Gambar 3 Model Penelitian analisis pengaruh koneksi militer terhadap tingkat suku bunga di perusahaan-perusahaan Indonesia. Sumber : Imam Harymawan (2017).

\section{RESEARCH METHODOLOGY}

Rancangan penelitian didefisinikan sebagai kerangka kerja pola dan teknik yang dipilih oleh seorang peneliti untuk menggabungkan berbagai komponen penelitian dengan cara yang cukup logis, sehingga masalah penelitian ditangani secara efisien. Ini memberikan wawasan tentang "bagaimana" melakukan penelitian menggunakan metodologi tertentu (Sukardi, 2003).

Seorang peneliti harus memiliki pemahaman yang jelas tentang berbagai jenis rancangan penelitian untuk memilih jenis desain penelitian yang akan diterapkan untuk studi. Rancangan penelitian secara luas diklasifikasikan ke dalam desain penelitian kuantitatif dan kualitatif (Nazir, 2005).

Dalam hal ini, sifat dari penelitianyang dirancang adalahkuantitatif denganpenekanan dalam pengukuran objektif dan analisis statistik. Penelitian kuantitatif dilaksanakan dalam kasus-kasus dimana penting bagi seorang peneliti agar memiliki kesimpulan statistik untuk mengumpulkan wawasan yang dapat ditindaklanjuti (Sugiyono, 2013). Penelitian yang dirancang bertujuan untuk mencari tahu bukti mengapa perusahaan menyatakan bahwa sejumlah personel militer telah ditunjuk sebagai anggota dewan oleh perusahaan-perusahaan yang telah tercatat di Indonesia.

Kumpulan sumber daya yang menyatukan konten investigasi atau pekerjaandalam penyelidikan ilmiah merupakan arti dari objek penelitian. Dalam konteks publikasi, objek penelitian mendukung apa yang dijelaskan dalam makalah, menjelaskan alat, kumpulan data, pertanyaan, dan eksekusi yang digunakan untuk mencapai hasil akhir (Made Wirartha, 2006).

Objek penelitian mengklaim untuk menggambarkan realitas yang benar dan tepat,serta independen dari mereka yang terlibat dalam proses penelitian. Meskipun ini adalah pandangan yang sederhana tentang cara di mana penelitian dapat ditemui, inimerupakan perbedaan yang penting untuk dipikirkan (Arikunto, 2009).

Tujuan dari objekpenelitian ini untuk menciptakan kelas artefak yang dapat merangkum pengetahuan digital dan menyediakan mekanisme untuk berbagi,serta menemukan aset penelitian yang dapat digunakan kembali dari pengetahuan ilmiah (Sugiyono, 2013).

Penelitian ini memiliki kriteriakriteria yang telah diterapkan dalam pengambilan sampel, sebagai berikut:

1. Perusahaan yang ada di Bursa Efek Indonesia (BEI) dari tahun 2013 hingga 2017.

2. Memiliki data yang membantu agar dapat menghitung jumlah nilai variabel dependen dan independen.

3. Data yang dibutuhkan untuk pengukuran variabel maupun pengukuran variabel dependen, independen, dan kontrol harus ada.

\section{Variabel Dependen}

Variabel dependen merupakan variabel yang dipengaruhi atau yang menjadi akibat dari adanya variabel independen (Sugiyono, 2013). Tingkat 
suku bunga berperan sebagai dependen didalam penelitian ini.

Tingkat suku bunga dapat dikatakan sebagai proporsi biaya yang dipinjamkan oleh pemberi pinjaman sebagai bunga kepada peminjam, biasanya dinyatakan sebagai persentase dari jumlah total pinjaman. Suku bunga biasanya sangat penting untuk diperhitungkan sebab rata-rata investor selalu mengharapkan pengembalian investasi yang lebih tinggi (Mishkin, 2008).

Tingkat Suku Bunga $=\underline{\text { Beban Bunga }}$

$$
\text { Rata-Rata Hutang }
$$

\section{Variabel Independen}

Variabel independen yaituvariabel yang diubah atau dikendalikan dalam percobaan ilmiah untuk menguji efek pada variabel dependen.Ketika eksperimen mengubah variabel independen, maka efek pada variabel dependen akan diamati dan dicatat (Sugiyono, 2013). Variabel independen yang dipakaiuntuk penelitian ini yaitu koneksi militer. Berikut penjelasannya:

\section{Koneksi Militer}

Koneksi militerdapat dikatakan sebagai pengganti kualitas tata kelola yang dibutuhkan oleh perusahaan untuk mengurangi biaya bunga di negara berkembang. Peneliti menemukan bahwa di Indonesia, militer juga memainkan peran yang sama sebagai politikus yang memberikan manfaat bagi koneksi bisnis dengan menggunakan pengaruh baik atau buruknya koneksi politik dan koneksi militer (Crouch, 1978).

$$
\text { Cho dan Rui (2009) }
$$

mengemukakan bahwa Indonesia merupakan salah satu dari beberapa negara yang mengadopsi struktur dewan dua tingkat.Dalam jenis struktur dewan ini, perusahaan-perusahaan yang terdaftar diharuskan memiliki dewan direksi dan dewan komisaris.Namun dari uraian data dalam penelitian ini semua direktur yang terhubung secara militer hanya bertindak sebagai dewan komisaris.Cara pengukuran yang digunakan adalah dewan komisaris, dengan melihat apakah salah satu diantara dewan komisaris pernah menjadi mantan militer atau anggota TNI.

Koneksi militer $=$ Dewan komisaris yang pernah menjabat sebagai mantan militer

\section{Variabel Kontrol}

\section{Ukuran Perusahaan}

Ukuran perusahaan dinotasikan dengan SIZE yang merupakan ukuran dari perusahaan yang menjadi sampel penelitian. Ukuran perusahaan dapat disebut sebagai hal yang dapat mengukur seberapa besar kecilnya nilai suatu perusahaan atau suatu perbandingan besar kecilnya usaha organisasi (Ferry \& Jones, 2001).

Ukuran Perusahaan $=$ Ln $($ Total Asset $)$

\section{Tingkat Pengembalian Aset}

Tingkat pengambilan aset atau return on assets dinotasikan dengan ROA. Return on Assets adalah indeks seberapa bermanfaat perusahaan relatif terhadap total asetnya. Tingkat pengembalian aset dapat dikatakan sebagai jenis metrik pengembalian atas investasi yang mengukur profitabilitas bisnis terkait dengan total asetnya (Kasmir, 2012).

Rasio Return on Assets ini dapat menghasilkan pendapatan serta dapat menghasilkan laba, rasio ini dapat melihat seberapa berguna perusahaan dalam membantu investor untuk mengubah kapitalisasi dari aset menjadi laba. Semakin tinggi pengembaliannya, semakin produktif manajemen dan efisien dalam memanfaatkan sumber daya ekonomi (Munawir, 2010).

Rumus dari pengukuran return on assets sebagai berikut :

$$
\text { Return on assets }=\frac{\text { Net Income }}{\text { Total Assets }}
$$

\section{Leverage}

Leverage dinotasikan dengan $L E V$. Leverage dapat disebut sebagai istilah bisnis yang mengacu pada utang atau meminjam dana untuk membiayai pembelian inventaris, peralatan, dan aset 
perusahaan lainnya. Pemilik bisnis dapat menggunakan hutang atau ekuitas untuk membiayai atau membeli aset perusahaan (Harahap, 2004). Adapun rumus perhitungan efek pengungkit adalah sebagai berikut:

Leverage $=\underline{\text { Total Hutang }}$

$$
\text { Total Aset }
$$

\section{Rasio antara nilai pasar dengan nilai buku}

Nilai buku secara literasi artinya nilai dari suatu bisnis berdasarkan "buku" atau laporan keuangannya. Dalam hal ini, nilai buku dikalkulasikan dari neraca yang merupakan selisih antara total aset dan total liabilitas. Perlu dicatat juga bahwa ada istilah ekuitas dari pemegang saham, sedangkan nilai pasar merupakan nilai perusahaan berdasarkan pasar modal. Nilai pasar dapat dihitung dengan cara jumlah lembar saham perusahaan dikalikan dengan harga pasar saham tersebut(Irham Fahmi, 2013). Cara pengukuran market to book value dapat dirumuskan sebagai:

Nilai Pasar = Jumlah Saham Beredar $\mathrm{x}$ Harga Saham

Nilai Buku $=$ Total aset - Total liabilitas

Market to book value $=$ Market value

\section{Pertumbuhan Perusahaan}

Pertumbuhan merupakan perusahaan yang memiliki perubahan peningkatan total aktiva. Perubahan tersebut dapat dilihat dari perusahaan yang mengalami perubahan penurunan ataupun peningkatan total aktiva selama satu periode. Pertumbuhan aktiva dapat dihitung sebagai presentase perubahan aktiva (Kasmir, 2016).

Pertumbuhan $=\underline{\text { Total aset }- \text { Total aset }} \mathrm{t}-1$

$$
\text { Total aset } \mathrm{t}-1
$$

Data sekunder ialah data yang akandigunakan dalam penelitian ini yang merupakan data penelitian sebelumnya.Data ini dapat digunakan untuk meningkatkan ukuran sampel studi penelitian dan dipilih untuk efisiensi. Data sekunder ini juga dapat dilihat dari situs web BEI yaitu www.idx.co.id(Sugiyono, 2016).

Cara peneliti beralih dari kumpulan data ke wawasan yang bermakna merupakan pengertian dari metode analisis data.Ada banyak metode analisis data yang berbeda, tergantung pada jenis penelitian.Metode analisis regresi panel merupakan data yang digunakan dalam pengujian hipotesispenelitian ini.Sistem yang akandigunakan untuk menganalisis data ini adalahSPSSdan Eviews 7.

\section{RESEARCH FINDINGS Statistik Deskriptif}

Sampel penelitian yang akan dianalisa merupakan laporan tahunan yang tercatat di BEI dari tahun 2013-2017. Hasil pengambilan sampel penelitian terdapat pada tabel 4.1 :

Tabel 4.1

\begin{tabular}{lcc} 
Daftar Jumlah Perusahaan yang Dijadikan Sampel \\
\\
\hline Keterangan & \multicolumn{2}{c}{ Jumlah } \\
\hline Jumlah perusahaan yang terdaftar di BEI & 597 & Perusahaan \\
Jumlah perusahaan yang tidak memenuhi kriteria & -165 & Perusahaan \\
\cline { 2 - 4 } Jumlah perusahaan yang memenuhi kriteria & 432 & Perusahaan \\
Periode penelitian & 5 & Tahun \\
Jumlah data perusahaan periode 2013-2017 & 2.160 & Data \\
Jumlah data outlier & -85 & Data \\
\cline { 2 - 4 } Jumlah data perusahaan yang bebas outlier & 2.075 & Data \\
\hline Sumber: Data sekunder yang diolah (2019). & &
\end{tabular}

Tabel 4.1 memperlihatkan perusahaan dari tahun 2013 hingga 2017 yang terdaftar di BEI terdapat sejumlah 597 perusahaan, sedangkan jumlah perusahaan yang memcukupi kriteria ada 432 perusahaan. Jumlah data observasi perusahaan sebanyak 2.160 data, dan terdapat data outlier sebanyak 85 data, maka jumlah data yang dianalisis ada 2.075 data. Hasil dari uji statistik deskriptif ditunjukkan pada Tabel 4.2.

Tabel 4.2

\begin{tabular}{|c|c|c|c|c|c|}
\hline & $\mathrm{N}$ & Min & Max & Mean & $\begin{array}{c}\text { Std. } \\
\text { Deviasi }\end{array}$ \\
\hline Tingkat Suku Bunga & 2075 & $-0,0277$ & 0,1124 & 0,3650 & 0,2752 \\
\hline $\begin{array}{l}\text { Ukuran Perusahaan } \\
\text { (dalam jutaan Rupiah) }\end{array}$ & 2075 & 22,2772 & 34,6811 & 28,7318 & 1,880 \\
\hline $\begin{array}{l}\text { Tingkat Pengembalian } \\
\text { Aset }\end{array}$ & 2075 & $-1,2791$ & 2,1920 & 0,0290 & 0,1422 \\
\hline Leverage & 2075 & 0,0002 & 13,1473 & 0,5832 & 0,6767 \\
\hline $\begin{array}{l}\text { Rasio antara Nilai Pasar } \\
\text { dengan Nilai Buku }\end{array}$ & 2075 & $-1951,3761$ & 58486,7101 & 96,4707 & 2016,7059 \\
\hline Pertumbuhan & 2075 & $-0,9557$ & 426,5772 & 0,3991 & 9,419 \\
\hline Valid N (listwise) & 2075 & & & & \\
\hline
\end{tabular}

Hasil Uji Statistik Deskriptif

Pada tabel 4.2 merupakan variabel yang diteliti yang menunjukkan nilai 
minimum, maksimun, rata-rata, dan standar deviasi. Hasilnya memperlihatkan nilai rata-rata tingkat suku bunga sebesar 0,3650 lebih besar dari standar deviasi sebesar 0,2752 yang berarti data tingkat suku bunga perusahaan pada tahun 20132017 tidak bervariasi. Nilai minimum dan maksimum masing-masing dari tingkat suku bunga sebesar $-0,0277$ dan 0,1124 . Nilai minimum diperoleh dari PT. Alumindo Light Metal Industry Tbk yang mengalami kemerosotan hutang jangka pendek, hal ini disebabkan pada tahun 2017 telah mengalami penurunan pada harga bahan baku aluminium, selain itu dibandingkan dengan tahun lalu nilai ekuitas senilai Rp. 565 miliar menurun drastis sebanyak $8,1 \%$, hal ini karena perusahaan yang mengalami kerugian disebabkan oleh munculnya persaingan global yang sangat ketat dalam bisnis aluminium dan juga karena biaya bunga, serta kerugian mata uang asing. Nilai maksimum diperoleh dari PT. BFI Finance Indonesia Tbk. Direktur BFI Finance Indonesia Tbk menanggapi kebijakan Bank Indonesia dalam meningkatkan suku bunga hingga 150 bps sejak bulan mei 2017 tentu berpengaruh pada cost of fund industri pembiayaan. BFI Finance turut meningkatkan pembiayaan bunga antara 0,5\% - 1,0\% di bulan September 2017 lalu.

Nilai rata-rata dari variabel kontrol ukuran perusahaan yang tercatat di BEI sebesar dua puluh delapan triliun rupiah dan nilai standar deviasi lebih kecil dari rata-rata yaitu sebesar 1,880 yang artinya data tidak bervariasi. Nilai minimum dari variabel kontrol ukuran perusahaan adalah PT. Rimo International Lestari Tbk sebesar dua puluh dua triliun rupiah, sedangkan nilai maksimum dari variabel kontrol ukuran perusahaan sebesar tiga puluh empat triliun rupiah yang diperoleh dari PT. Bank Rakyat Indonesia (Persero) Tbk.

Variabel tingkat pengembalian aset memiliki nilai rata-rata sebesar 0,0290 dan nilai standar deviasi lebih besar dari ratarata yaitu 0,1422 yang berarti data bervariasi. Nilai minimum tingkat pengembalian aset sebesar -1.2791 yang dimiliki oleh PT. ICTSI Jasa Prima Tbk pada tahun 2015. Harga saham PT. ICTSI mengalami penurunan drastis yakni sebesar $57,16 \%$ atau sekitar Rp 168 menjadi Rp 126 per saham pada akhir tahun 2015, sedangkan untuk nilai maksimum dari variabel tingkat pengembalian aset sebesar 2,1920 yang dimiliki oleh PT. Steady Safe Tbk pada tahun 2016.

Hasil pengujian statistik deskriptif memperlihatkan rata-rata leverage sebesar 0,5832 yang berarti rata-rata entitas tercatat di BEI mendanai modal perusahaan dengan utang sebesar $58 \%$. Nilai standar deviasi dari leverage sebesar 0,6767 lebih besar dari nilai rata-rata yang menunjukkan bahwa data tersebut bervariasi. Nilai minimum dan maksimum masing-masing sebesar 0,0002 dan 13,1473. Nilai minimum diwakilkan oleh PT. Sumber Energi Andalan Tbk, diketahui laba PT. Sumber Energi Andalan Tbk turun sebesar 3,62\% pada tahun 2015. Nilai maksimum dimiliki oleh PT Rimo International Lestari Tbk sebesar 13,1473, pendapatan PT Rimo International Lestari Tbk diketahui mengalami kenaikan yang cukup fantastis sepanjang kuartal kedua tahun 2017. Berdasarkan laporan keuangan perseroan, pendapatan emiten PT Rimo International Lestari Tbk tercatat senilai Rp. 241,65 miliar, padahal pada kuartal pertama lalu pendapatan PT Rimo International Lestari Tbk baru mencapai Rp. 77,1 miliar.

Rasio antara nilai pasar dengan nilai buku memiliki nilai rata-rata sebesar 96,4707 lebih kecil dari standar deviasi yang memiliki jumlah sebesar 2016,7059 yang artinya data tersebut bervariasi. Nilai minimum dari rasio antara nilai pasar dengan nilai buku adalah -1951,3761 yang diwakili oleh PT. Sekawan Intipratama Tbk. Harga saham PT. Sekawan Intipratama Tbk mengalami penurunan sejumlah 64,68\% atau Rp 152 dari harga penutupan Rp 235 menjadi Rp 83 pada tahun 2016. Nilai maksimum dari rasio 
antara nilai pasar dengan nilai buku adalah 58486,7101 yang diwakili oleh PT. Baramulti Suksessarana Tbk. Pendapatan yang diperoleh PT. Baramulti Suksessarana Tbk mengalami peningkatan sebesar 75\%. Berdasarkan laporan keuangan perseroan, total aset PT. Baramulti Suksessarana Tbk tercatat senilai Rp 162,7 juta. Sementara, return on equity $(R O E)$ tercatat sebanyak $8,8 \%$.

Nilai rata-rata dari pertumbuhan adalah 0,399 lebih kecil dari nilai standar deviasi sebesar 9,419 yang menunjukkan data tersebut bervariasi. Nilai minimum dari pertumbuhan sebesar -0,9557 yang diwakili oleh PT. Renuka Coalindo Tbk. Harga saham PT. Renuka Coalindo Tbk diketahui mengalami penurunan cukup drastis sebesar $79,76 \%$ dari posisi akhir tahun 2016 Rp. 1640 menjadi Rp. 332. Nilai maksimum dari pertumbuhan sebesar 426,5772, nilai ini diwakili oleh PT. Indoritel Makmur Internasional Tbk. Saham Indoritel Makmur Internasional Tbk mengalami gain atau kenaikan senilai $25,71 \%$ pada tahun 2017 Tabel 4.3

Hasil Uji Statistik Variabel Koneksi Militer

\begin{tabular}{llrc}
\hline \hline Variabel & Kategori & Freknensi & Persentase \\
\hline Koneksi Militer & $0=$ Non Koneksi Militer & 1924 & $92,7 \%$ \\
& $1=$ Koneksi Militer & 151 & $7,3 \%$ \\
\hline \hline
\end{tabular}

Sumber: Data diolah (2019).

Tabel 4.3 diatas menjelaskan bahwa non koneksi militer memperoleh persentase sebesar $92,7 \%$ yang artinya tidak ada satupun dewan komisaris yang merupakan mantan militer atau anggota TNI, sedangkan persentase $7,3 \%$ diperoleh koneksi militer, maka ada salah satu diantara dewan komisaris yang merupakan mantan militer ataupun anggota TNI.

\section{Pemilihan Metode Terbaik Hasil Uji Chow}

Tabel 4.4

\begin{tabular}{lcr} 
Hasil Uji Chow & & \\
\hline \hline Effects Test & Prob. & Kesimpulan \\
\hline Cross-section Chi-square & 0,0000 & Fixed Effect model \\
\hline
\end{tabular}

Sumber: Data diolah, 2019.

Uji chow digunakan untuk mendefinisikan metode mana yang akan digunakan antara pooled least square (PLS)dan fixed effect model (FEM). Hasil uji chow dapat dilihat dari angka probabilitas pada Cross Section Chi Square. Jika nilai probabilitasnya lebih besar dari 0,05, maka model yang akan digunakan ialah pooled least square. Sebaliknya, jika nilai probabilitasnya lebih kecil dari 0,05 maka model yang akan digunakan ialah fixed effect model.

\section{Hasil Uji Hausman}

Tabel 4.5

Hasil Uji Hausman

\begin{tabular}{llr}
\hline \hline Effects Test & Prob. & Kesimpulan \\
\hline Cross-section random & 0,0183 & Fixed Effect model \\
\hline
\end{tabular}

Sumber: Data diolah, 2019.

Uji Hausman berfungsi untuk menentukan antara fixedeffectmodel atau randomeffectmodel mana yang akan digunakan.Hasil uji Hausmandapatdilihat dari nilai cross section random. Pemilihan dalam menentukan model, apabila nilai probabilitasnya lebih tinggi dari nilai 0,05 , maka model yang digunakan ialah REM, tetapi sebaliknya apabila nilai probabilitasnya lebih rendah dari nilai 0,05 , maka yang digunakan adalah FEM.

\begin{tabular}{|c|c|c|}
\hline \multicolumn{3}{|c|}{$\begin{array}{l}\text { Hasil Uji Hipotesis } \\
\text { Hasil Uji F } \\
\text { Tabel } 4.6\end{array}$} \\
\hline \multicolumn{3}{|l|}{ Hasil Uji F } \\
\hline Variabel Dependen & Sig. & Kesimpulan \\
\hline Tingkat Sulku Bunga & 0,0000 & Signifikan \\
\hline
\end{tabular}


tingkat suku bunga adalah 0,000 yang artinya nilai signifikan tersebut lebih kecil dari 0,05 mendefinisikan bahwa variabel independen yang diteliti secara simultan berpengaruh signifikan terhadap tingkat suku bunga.

\section{Hasil Uji T}

Tabel 4.7

\begin{tabular}{lccl} 
Hasil Uji T & & & \\
\hline \hline Variable & Coefficient & Prob. & Kesimpulan \\
\hline Koneksi Militer & $-0,017534$ & 0,0000 & Signifikan Negatif \\
Ukuran Perrusahaan & 0,003950 & 0,0001 & Signifikan positif \\
Tingkat Pengembalian Aset & $-0,003001$ & 0,3006 & Tidak signifikan \\
Leverage & 0,000839 & 0,4031 & Tidak signifikan \\
Rasio antara Nilai Pasar dengan & & & \\
Nilai Buku & $2,44 \mathrm{E}-07$ & 0,6437 & Tidak signifikan \\
Pertumbuhan & $-0,000128$ & 0,0005 & Signifikan negatif \\
\end{tabular}

Sumber: Data diolah, 2019

$$
\text { Hasil dari tabel }
$$

memperlihatkan bahwa variabel koneksi militer memperoleh nilai probabilitas 0,0000 yang berarti signifikan negatif terhadap tingkat suku bunga. Perusahaan yang terhubung secara militer mendapatkan pinjaman preferensial dari bank pemerintah, ini menunjukkan bahwa bank sudah mengakui efek yang komersial dari koneksi militer dan memberikan pinjaman yang menguntungkan. Perusahaan yang terhubung secara militer dapat memudahkan bank untuk memiliki akses yang lebih besar dari dana terutama dari anggaran pemerintah dan proyekproyek BUMN dengan tingkat bunga yang lebih rendah, selain itu mereka juga dapat menggunakan bunga pinjaman yang lebih tinggi karena dapat memiliki kapasitas pasar yang lebih menguntungkan dalam meningkatkan kinerja (Khwaja dan Mian, 2005), dan (Boubakri et al., 2012), dan (Braun dan Raddatz, 2010, Nys et al., 2015).

Variabel kontrol ukuran perusahaan menunjukkan hasil signifikan positif terhadap tingkat suku bunga. Ukuran perusahaan dikaitkan dengan total aset perusahaan, yang menggambarkan sumber daya perusahaan berupa aset keuangan dan non keuangan. Ukuran perusahaan juga memoderasi integrasi pelanggan, kinerja bisnis, dan kinerja operasional, yang menggambarkan kemampuan perusahaan. Temuan ini memiliki hal yang sama dengan Zamora Ramirez (2016).

Hasil uji variabel kontrol tingkat pengembalian aset menunjukkan pengaruh tidak signifikan terhadap tingkat suku bunga.Tingkat pengembalian aset yang tinggi dapat menghasilkan laba tinggi yang diperoleh perusahaan.Laba tinggi menghasilkan kenaikan pajak yang harus dibayar oleh suatu perusahaan, sehingga perusahaan cenderung melakukan agresivitas pajak. Hasil penelitian ini sejalan dengan Dyreng, Hanlon, dan Maydew (2008), dan Richardson, Taylor, dan Lanis (2013), dan Kim dan Zhang (2016).

Hasil pengujian variabel kontrol leverage menunjukkan tidak signifikan terhadap tingkat suku bunga. Ini ada hubungannya dengan fakta bahwa perusahaan mungkin cenderung menggunakan pinjaman pemegang saham sebagai sumber pendanaan, sehingga biaya bunga yang muncul tidak lagi valid. Temuan ini sama dengan penelitian Alviyani dan Surya (2016).

Variabel kontrol rasio antara nilai pasar dengan nilai buku menunjukkan pengaruh tidak signifikan pada tingkat suku bunga.Hal ini dapat disimpulkan bahwa investor pasar tampaknya menghargai intervensi politik beberapa pemerintah untuk menyelamatkan bank dipecahnya krisis keuangan tahun 2008. Temuan ini sama dengan penelitian Dicko dan Breton (2013), dan Dicko dan Khemakhem (2015).

Variabel pertumbuhan memiliki pengaruh signifikan negatif terhadap tingkat suku bunga.Hal ini dapat disebabkan karena pertumbuhan yang lebih tinggi dari perusahaan mengarah ke fasilitas pembayaran pinjaman yang memberikan kreditur untuk memberikan tingkat suku bunga yang lebih rendah kepada perusahaan yang memiliki pertumbuhan yang lebih tinggi. Temuan 
penelitian ini sesuai dengan Chaney et al. (2011).

\section{Hasil UjiGoodness of Fit Model}

Tabel 4.8

Hasil Uji Adjusted R Square

\begin{tabular}{ll}
\hline \hline Variabel Dependen & Adjusted R Square \\
\hline Tingkat Sulku Bunga & 0,741282 \\
\hline \hline
\end{tabular}

Sumber: Data diolahi, 2019.

Dari hasil uji diatas menunjukkan bahwa adjusted $R$ square sebesar 0,741282 atau $74,12 \%$ yang berarti variabel dependen yang terdapat dalam penelitian ini hanya dapat menjelaskan tingkat suku bunga sebesar $74,12 \%$, sedangkan $25,88 \%$ dijelaskan oleh variabel yang tidak digunakan dalam model penelitian ini.

\section{Uji Kualitas Data}

\section{Uji Outlier}

Tujuan dari uji outlier ialah untuk mengidentifikasikan apakah data tersebut ada yang menyebabkan hasil uji menjadi tidak wajar dan tidak menggambarkan data sesuai dengan standar. Berdasarkan total data yang diuji terdapat 54 data outlier sehingga sampel yang diuji dalam penelitian ini terdapat sebanyak 2.106 data. Data akan dianggap outlierjika nilainya lebih besar dari 1,96 dan lebih kecil dari 1,96. Hasil outlier dilihat berdasarkan Studentized Deleted Residual (SDR).

\section{Hasil Uji Regresi Panel}

Uji regresi panel bertujuan untuk mendefinisikan model yang paling sesuai antara pooled least squares (PLS), fixed effect model (FEM), dan random effect model (REM) denganmenggunakan ujichow dan uji hausman.

\section{CONCLUSION}

Penelitian ini berfungsi untuk memberikan bukti empiris tentang pengaruh koneksi militer terhadap tingkat suku bunga pada perusahaan-perusahaan yang terdaftar di Indonesia. Terdapat kesimpulanyang bisa dikutip berdasarkan hasil analisisyang diperoleh dalam menguji sampel sebagian perusahaan pada tahun 2013 hingga 2017 yang terdaftar di BEI berupa: koneksi militer, tingkat pengembalian aset, leverage, rasio antara nilai pasar dengan nilai buku tidak berpengaruh signifikan terhadap tingkat suku bunga, sedangkan untuk ukuran perusahaan dan pertumbuhan masingmasing berpengaruh signifikan terhadap tingkat suku bunga.

\section{Keterbatasan}

Terdapat keterbatasan pada penelitian ini sebagai berikut:

1. Tercatat ada laporan keuangan yang tidak lengkap pada sebagian perseroan dari tahun 2013-2017 yangterdaftar di BEI.

2. Sampel pada penelitian tertuju untuk perseroan yang ada di BEI.

\section{Rekomendasi}

Beberapa rekomendasi kepada penelitian yang akan datang, yaitu:

1. Dapat menambahkan variabel penelitian yang belum ada pada penelitian ini seperti variabel koneksi militer, tingkat suku bunga, dan beberapa variabel lainnya.

2. Memperluas jangkauan komunitas penelitian dengan cara melakukan studi komperatif antar negara.

\section{REFERENCES}

Fisher (2017). The Impact of Interest Rate on Economic Development: a Study on Asian Countries. International Journal of Accounting \& Business Management,5(1),180-188.

Goldfajn \& Baig (2016). Impact of Shortterm Interest Rate on Exchange Rate : Procedia Economics and Finance, 38, 195-202.

Neumeyer \& Perri (2007). The Impact of Foreign Interest Rates on the Economy:The Role of the Exchange Rate Regime.

Chaney et al. (2011) Political Connections and Cost of Debt Financing: Empirical Evidence from China. 
International Journal of Economics and Financial Issues, 9(1), 212-216.

Bose (2002). The long run relationship between interest rates and inflation in Iran: Revisiting Fisher's hypothesis. Journal of Economics and International Finance, 3(14), 705712.

Ha \& Choi (2010). When do interest rates matter? Two methodological approaches to loyalty. Asia Pacific Journal of Marketing and Logistics.

Laksmono (2001) Dynamic lag structure of deposits and loans interest rates and business cycles formation. Journal of Financial Regulation and Compliance, 25(2), 114-132.

Abdullah, (2010). Determinants of interest rate in emerging markets: A study of banking financial institutions in Uganda. World Journal of Entrepreneurship, Management and Sustainable Development, 14(3), 267290.

Bernanke \& Gertler (1995). Why Do Bank-Dependent Firms Bear InterestRate Risk? IMF Working Papers, 17(3), 1.

Blinder, (2012). Securitization and financial markets: the implications for interest rate pass-through. Journal of Financial Economic Policy, 8(4), 472-498.

Cunha, M., \& Menezes, C. (2016). Funnell, W. (2005). Accounting on the frontline: cost accounting, military efficiency, and the South African War. Accounting and Business Research,35(4), 307-326. 1-45.

Demirgüç-Kunt and Huizinga, (1999). Macroeconomic determinants of interest rate spreads in Ghana. African Journal of Economic and Management Studies, 8(1), 76-88.

Duffy, T. (2006). Military Experience. \& Ceo. Duffy, T. (2006). Military Experience \& CEOs: Is There a Link?. Korn/Ferry International. (5), 2014-2017.

Faccio, M. (2016). Kim, C. F., \& Zhang,
L. (2015). Corporate political connections and tax aggressiveness. Contemporary Accounting Research. Contemporary Accounting Research, 33(1), 115-120.

Goldman, E., Rocholl, J., \& So, J. (2009). Politically connected boards of directors and the allocation of procurement contracts. Review of Finance. Review of Finance, 17(5), 132.

Kaidesoja, J. (2018). Lin, C., Ma, Y., Officer, M., Zou, H. (2014). CEOs' military experience and acquisition decisions. Available at SSRN.

Kim, J. B., Song, B. Y., \& Zhang, L. (2011). Kim, J. B., Song, B. Y., \& Zhang, L. (2011b). Internal control weakness and bank loan contracting: Evidence from SOX Section 404 disclosures. The Accounting Review, 86(4), 1157-1188. Accounting Review, 86(4), 1157-1188.

Braun and Raddatz, (2010). Transactional and Relational Approaches to Political Connections and the Cost of Debt Transactional and Relational Approaches to Political Connections and the Cost of Debt.

Khwaja and Mian, (2017). Politically connected banks: Some Indonesian evidence. International Journal of Business and Society, 18(1), 83-94.

Nazarian and Amiri (2016). The response of bank of Indonesia's interest rates to the prices of world crude oil and foreign interest rates. International Journal of Energy Economics and Policy, 6(2), 266-272.

Mietzner Marcus, (2006). The politics of military reform in post-Suharto Indonesia elite conflict, nationalism, and institutional resistance.

Bliss, M. A., \& Gul., F. A. (2012). Political connection and cost of debt: Some Malaysian evidence. Journal of Banking \& Finance, 36(5), 2011)

Agrawal, A., \& Knoeber, C. R. (2001). Do Some Outside Directors Play a Political Role? Do Some Outside

Program Studi Akuntansi, Fakultas Ekonomi, Universitas Internasional Batam |77 
Directors Play a Political Role? Journal of Law and Economics, 44(1), 179-198.

Nys, E., Tarazi, A., \& Trinugroho, I. (2015). Political connections, bank deposits, and formal deposit insurance. Journal of Financial Stability, 19, 83-104.

Trinugroho, I., Agusman, A., \& Tarazi, A. (2014). Why have bank interest margins been so high in Indonesia since the 1997/ 1998 financial crisis? Research in International Business and Finance, 32, 139-158.

Faust, J., Rogers, J.H., Shing-Yi, B.W. and Wright, J.H. (2007), "The highfrequency response, of exchange rates and interest rates to macroeconomic announcements", J. of, \& Monetary Economics, Vol. 54, pp. 1051-1068.

Irwanto Agus \& Mukhlis, 2012. (2012). Pengaruh Tingkat Suku BungaTerhadap Deposito Di Provinsi Aceh Berdasarkan Data Tahun 20052010. 1(1), 41

Hafizatul Fitria \& Asnawin (2018). Pengaruh Jumlah Uang Beredar,Tingkat Suku Bunga Dan Inflasi Terhadap Pertumbuhan Ekonomi Di Indonesia. Jurnal Ekonomika Indonesia, VII, 24-32.

Roseline N, Misati Esman M \& Nyamongo Anne W. Kamau (2015). Interest rate pass-through in Kenya", International Journal of Development Issues, Vol. 10 Iss 2 pp. 170 - 182.

Ahsan Habib \& Abdul Haris Muhammadi, (2011). Political connections and audit report lag: Indonesian evidence", International Journal of Accounting \& Information Management,. International Journal of Accounting \& Information Management, 19(3), 120-124.

Mariya Gubareva, M. R. B. 2017. (2008). Interest rate, liquidity, and sovereign risk: derivative-based VaR", The Journal of Risk Finance,. The Journal of Risk Finance, 16(5), 498-518.

Rieffel, A., Pramodhawardani, J. (2007).
Out of business and on budget: the challenge of military financing in Indonesia: Brookings Institution Press. Forum Bisnis Dan Kewirausahaan Jurnal Ilmiah STIE MDP Hal-59, 2(1), 59-68.

Shah, A. (2014). Constraining consolidation: military politics and democracy in Pakistan (2007-2013). Democratization, 21(6), 1007-1033.

Misol, L. (2006). Too High a Price: The Human Rights Cost of the Indonesian Military's Economic Activities", Vol. 18 No. 5C, Human Right Watch, pp.

Sebastian, L. C. (2013). Taking stock of military reform in Indonesia", in Rüland, J., Manea, M.-G. and Born, H., The Politics of Military Reform Experiences from Indonesia pp. 2956.

Moeen Umar Cheema, (2016). Political connections and organisational performance: evidence from Pakistan", International Journal of Accounting \& Information Management.

Leuz, C. and Oberholzergee, F. (2006). "Political relationships, global financing, and corporate transparency: evidence from Indonesia", Journal of Financial Economics.

Kim, S. (2015). "The factors that influence bank customer loyalty in bank loan services", Financial Planning Review, Vol. 8 No. 1, pp. 29-54. 1-5.

Bhakti, I. N., Yanuarti, S. and Nurhasim, M. (2009). "Military politics, ethnicity and conflict in Indonesia", working paper, Centre for Research on Inequality, Human Security and Ethnicity, University of Oxford, Oxford, January. XXI(2), 262-285.

Mobarak, A. M. and Purbasari, D. P. (2006). "Corrupt protection for sale to firms: Evidence from Indonesia", working paper, University of Colorado at Boulder, Boulder, 15 April.

Gul, F. A. (2006). “Auditors"' Response to

Program Studi Akuntansi, Fakultas Ekonomi, Universitas Internasional Batam | 78 
Political Connections and Cronyism in Malaysia", Journal of Accounting Research, Vol. 44 No. 5, pp. 931963."

Ivanova, D., Lahiri, K. and Seitz, F. (2000). "Interest rate spreads as predictors of German inflation and business cycles", International Journal of Forecasting.

Ahokpossi, C. (2013). "Determinants of bank interest margins in Sub-Saharan Africa”, IMF Working Paper No. 13/34, International Monetary Fund, Washington, DC. (I), 1-43.

Al-Muharrami, S. (2015). "Interest rate in Oman: is it fair?", Humanomics, Vol. 31 No. 3, pp. 330-343. 1-11.

Chirwa, E.W. and Mlachila, M. (2004). "Financial reforms and interest rate spreads in the commercial banking system in Malawi”, IMF Staff Papers, Vol. 51 No. 1, pp. 96-122.

Folawewo, A.O. and Tennant, D. (2008a). "Determinants of interest rate spreads in Sub-Saharan African countries: a dynamic panel data analysis", paper presented at the 13th African Econometric Society Conference, Pretoria, July 9-11.

Folawewo, A.O. and Tennant, D. (2008b). "Macroeconomic and market determinants of interest rate spreads in low- and middle-income countries", Applied Financial Economics, Vol. 19 No. 6, pp. 489507.

Kasturirangan, S. (2012). (2004). Examining the relationship between higher interest rates and nonperforming assets of banksevidence from Indian banking system", International Journal of Marketing, Financial Services \& Management Research, Vol. 1 No. 12, pp. 102-109.

Ndung'u, N. and Ngugi, R.W. (2000). "Banking sector interest rate spreads in Kenya", Discussion Paper No. 5, Kenya Institute for Public Policy Research and Analysis, Nairobi.

Were, M. and Wambua, J. (2015). "Assessing the determinants of interest rate spreads in commercial banks in Kenya: 'an empirical investigation”, Working Paper Series No. WPS/01/15, The Kenya Bankers Association (KBA), Nairobi. 1-34.

Cumby, R.E., Mishkin, F. S. (1986). The international linkage of real interest rates: The European-US connection. Journal of International Money and Finance, 5, 5-23. Workshop Pertanian YLBHI, (2), 1-13.

Kim, S.J., Sheen, J. (2000). International linkages and macroeconomic news effects on interest rate volatility Australia and The US. Pacific- Basin Finance Journal, 8, 85-113.

Chia, J., Liaoa, J. dan Chen, X. (2015). Political Connected CEOs and Earnings Management: Evidence from China. Journal of Economic Literature 92: 312-341. 